\title{
Photobacterium swingsii sp. nov., isolated from marine organisms
}

\author{
Bruno Gomez-Gil, ${ }^{1}$ Ana Roque, ${ }^{2}$ Guiomar Rotllant, ${ }^{2}$ Lauro Peinado, $^{1}$ \\ Jesus L. Romalde, ${ }^{3}$ Alejandra Doce, ${ }^{3}$ Hector Cabanillas-Beltrán, ${ }^{4}$ \\ Luciane A. Chimetto ${ }^{5}$ and Fabiano L. Thompson ${ }^{5}$ \\ ${ }^{1}$ CIAD, A.C. Mazatlán Unit for Aquaculture and Environmental Management, AP. 711 Mazatlán, \\ Sinaloa, Mexico \\ ${ }^{2}$ Institut de Reçerca i Tecnologia Agroalimentaries, Centre d'Aquicultura, Sant Carles de la Rapita, \\ Spain \\ ${ }^{3}$ Departamento de Microbiología y Parasitología, CIBUS-Facultad de Biología, Universidad de \\ Santiago de Compostela, 15782, Spain \\ ${ }^{4}$ Instituto Tecnológico de Tepic, Nayarit, Mexico \\ ${ }^{5}$ Universidade Federal de Rio de Janeiro, Rio de Janeiro, Brazil
}

Correspondence

Bruno Gomez-Gil bruno@ciad.mx
Six Gram-negative coccobacilli were isolated from Pacific oysters (Crassostrea gigas) from Mexico and haemolymph of spider crabs (Maja brachydactyla) from Spain. All of the isolates grew as small green colonies on thiosulphate-citrate-bile salts-sucrose (TCBS) agar and were facultatively anaerobic, oxidase-positive and sensitive to the vibriostatic agent O/129. Repetitive palindromic PCR analysis revealed a high degree of genomic homogeneity among the isolates. Several phenotypic traits differentiated the isolates from the type strains of species of the genus Photobacterium. DNA-DNA relatedness between two representative isolates and their closest phylogenetic neighbours by $16 \mathrm{~S}$ rRNA gene sequence similarity, Photobacterium aplysiae CAIM $14^{\top}$ and Photobacterium frigidiphilum CAIM $20^{\top}$, was $44.01-53.85 \%$. We propose a novel species of the genus Photobacterium to accommodate the six isolates, with the name Photobacterium swingsii sp. nov. The type strain is CAIM $1393^{\top}\left(=\right.$ CECT $\left.7576^{\top}\right)$.
Photobacterium is one of the oldest established genera in the family Vibrionaceae of the class Gammaproteobacteria. The type species is Photobacterium phosphoreum Beijerinck 1889, which had been described by Ferdinand Cohn in 1878 as 'Micrococcus phosphoreus'. At the time of writing, the genus Photobacterium contained 17 species (http:// www.vibriobiology.net). The genus has a worldwide distribution and most species include strains that exhibit luminescence and that are able to grow not only with general media but also with selective media, such as thiosulphate-citrate-bile salts-sucrose (TCBS), which is widely used for vibrio isolation. Some strains (Photobacterium damselae subsp. piscicida) are pathogenic for aquatic animals, but most strains have no described pathogenic traits and are common inhabitants of marine ecosystems and marine animals.

Abbreviation: rep-PCR, repetitive palindromic PCR.

The GenBank/EMBL/DDBJ accession numbers for the 16S rRNA gene sequences of strains CAIM 1439, CAIM 1206, CAIM 1119, CAIM 1394, CAIM 1395 and CAIM 1393 ${ }^{\top}$ are GQ386816-GO386818 and GQ386820-GQ386822, respectively.
During a survey of vibrios in cultured oysters in Mexico and haemolymph of wild spider crabs in Spain, genomic characterization by repetitive palindromic PCR (rep-PCR) revealed that six isolates were closely related and formed a cluster that was separate from all of the other isolates analysed. These six isolates were cultured from homogenates of the Pacific oyster (Crassostrea gigas), collected from three different localities in Mexico and the haemolymph of spider crabs (Maja brachydactyla), collected from the wild in the Canary Islands (Table 1). Another two strains were isolated from corals in Brazil but died before they could be characterized and only the 16S rRNA gene sequence of one (R13) was obtained. The isolates grow on TCBS agar as small, green, round colonies with smooth borders, 2-3 $\mathrm{mm}$ in diameter, and were non-luminescent. On marine agar after $24 \mathrm{~h}$ incubation, colonies were white and smooth, 2-3 mm in diameter, and were nonluminescent. Strains CAIM 1119 and CAIM 1206 showed weak agarolytic activity on marine agar.

Phenotypic characterization of the isolates used standard methods as described elsewhere (Macián et al., 2001) and the API 20E and API ZYM systems (bioMérieux), using 
Table 1. Origins of strains of Photobacterium swingsii sp. nov.

\begin{tabular}{|c|c|c|c|c|}
\hline Strain & Source & Locality & Isolation date & Coordinates \\
\hline CAIM 1439 & Pacific oyster homogenate & $\begin{array}{c}\text { Manuela lagoon, Mulegé, } \\
\text { Baja California, Mexico }\end{array}$ & 7 November 2003 & $28^{\circ} 01^{\prime} 23^{\prime \prime} \mathrm{N} 114^{\circ} 06^{\prime} 22^{\prime \prime} \mathrm{W}$ \\
\hline CAIM 1119 & Pacific oyster homogenate & $\begin{array}{l}\text { El Cardón estuary, Baja } \\
\text { California Sur, Mexico }\end{array}$ & 7 November 2003 & $26^{\circ} 47^{\prime} 36^{\prime \prime} \mathrm{N} 108^{\circ} 50^{\prime} 53^{\prime \prime} \mathrm{W}$ \\
\hline CAIM 1206 & Pacific oyster homogenate & La Cruz, Sinaloa, Mexico & 13 February 2004 & $24^{\circ} 05^{\prime} 44^{\prime \prime} \mathrm{N} 108^{\circ} 50^{\prime} 46^{\prime \prime} \mathrm{W}$ \\
\hline $\begin{array}{c}\text { CAIM } 1393^{\mathrm{T}} \text {, } \\
\text { CAIM } 1394, \\
\text { CAIM } 1395\end{array}$ & Spider crab haemolymph & $\begin{array}{l}\text { Taliarte Bay, Gran Canaria, } \\
\text { Canary Islands, Spain }\end{array}$ & 30 November 2006 & $27^{\circ} 59^{\prime} \mathrm{N} 15^{\circ} 22^{\prime} \mathrm{W}$ \\
\hline
\end{tabular}

cultures prepared on TSA plus $2.0 \% \mathrm{NaCl}$ and cell suspensions prepared in $2.5 \%$ sterile saline solution to a density that equalled 0.5 MacFarland standard. Tests included temperature and $\mathrm{NaCl}$ required for growth, several biochemical characteristics and the use of 49 substrates as sole carbon and energy sources. The results of the phenotypic characterization are presented in the species description and Tables 2 and 3. Several phenotypic characteristics differentiated the isolates from the type strains of closely related species of the genus Photobacterium and some differed among the isolates.

The 16S rRNA gene was amplified using universal primers (V16S-9F, 5'-AGAGTTTGATCATGGCTCAG-3'; V16S1491R, 5'-AGCGCTACCTTGTTACGACTT-3') and a thermal cycling program of $94{ }^{\circ} \mathrm{C}$ for $2 \mathrm{~min}, 35$ cycles at $94{ }^{\circ} \mathrm{C}$ for $1 \mathrm{~min}, 56{ }^{\circ} \mathrm{C}$ for $1 \mathrm{~min}$ and $72{ }^{\circ} \mathrm{C}$ for $1 \mathrm{~min}$ and finally $72{ }^{\circ} \mathrm{C}$ for $5 \mathrm{~min}$. Purification and sequencing of the amplification products was done at Macrogen (Korea). The sequences of the isolates were analysed with those of type strains of the genus Photobacterium available in public databases, using the consensus when more than one sequence of a strain was available. Phylogenetic analysis was conducted in MEGA4 (Kumar et al., 2001) using evolutionary distances computed using the maximumcomposite-likelihood method (Tamura et al., 2004) and the neighbour-joining method (Saitou \& Nei, 1987) to infer evolutionary history. Alignment gaps and missing data were eliminated only in pairwise sequence comparisons (pairwise deletion option). Bootstrap calculations (Felsenstein, 1985) were based on 1000 replicates. The Jukes-Cantor correction was used in the calculation of $16 \mathrm{~S}$ rRNA gene sequence similarity. An almost-complete sequence $(>1450 \mathrm{bp})$ of the $16 \mathrm{~S}$ rRNA gene was obtained for each of the isolates. 16S rRNA gene sequence similarity among the isolates was $\geqslant 98.6 \%$. Phylogenetic analysis showed that the isolates belonged to the genus Photobacterium. The optimal tree with the sum of branch length $=0.1766$ is shown in Fig. 1. The isolates exhibited 96.8-95.6\% 16S rRNA gene sequence similarity to Photobacterium frigidiphilum SL13 ${ }^{\mathrm{T}}$ and 96.7-95.5\% similarity to Photobacterium aplysiae $\mathrm{GMD} 509^{\mathrm{T}}$.

Genomic characterization of the isolates and the reference strains P. frigidiphilum CAIM 20 ${ }^{\mathrm{T}}$, P. aplysiae CAIM $14^{\mathrm{T}}$ and $P$. phosphoreum CAIM $328^{\mathrm{T}}$ was performed using
rep-PCR fingerprinting, using methods described previously (Cabanillas-Beltran et al., 2006). Briefly, DNA was extracted using a Wizard genomic DNA purification kit (Promega) according to the manufacturer's instructions. The DNA was adjusted to a concentration of $50 \mathrm{ng} \mathrm{Hl}^{-1}$

Table 2. Phenotypic differences between Photobacterium swingsii sp. nov. and some of its closest phylogenetic neighbours

Strains: 1 , Photobacterium swingsii sp. nov. $(n=6) ; 2$, P. frigidiphilum CAIM $20^{\mathrm{T}}$; 3, P. aplysiae CAIM $14^{\mathrm{T}}$ (data from this study and Seo et al., 2005); 4, P. profundum CAIM $1796^{\mathrm{T}}$ (this study and Nogi et al., 1998); 5, P. lipolyticum CAIM $15^{\mathrm{T}}$ (this study and Yoon et al., 2005); 6, P. phosphoreum CAIM $328^{\mathrm{T}} ; 7$, P. iliopiscarium CAIM $909^{\mathrm{T}}$. Data were obtained in this study unless indicated. + , Positive; $(+)$, most strains positive; -, negative; ND, no data available.

\begin{tabular}{|c|c|c|c|c|c|c|c|}
\hline Characteristic & 1 & 2 & 3 & 4 & 5 & 6 & 7 \\
\hline Arginine dihydrolase & + & - & + & + & - & + & + \\
\hline Lysine decarboxylase & - & + & - & - & - & - & - \\
\hline Citrate utilization & - & + & - & $\mathrm{ND}$ & ND & - & + \\
\hline Indole production & - & - & - & + & + & - & - \\
\hline Gelatin hydrolysis & $(+)$ & + & + & $\mathrm{ND}$ & - & - & - \\
\hline \multicolumn{8}{|l|}{ Growth with/at: } \\
\hline $6 \% \mathrm{NaCl}$ & + & + & - & + & - & - & + \\
\hline $4{ }^{\circ} \mathrm{C}$ & $(+)$ & - & - & + & + & + & + \\
\hline $30{ }^{\circ} \mathrm{C}$ & + & + & + & - & + & + & + \\
\hline \multicolumn{8}{|l|}{ Utilization of: } \\
\hline L-Arabinose & + & + & - & - & - & + & + \\
\hline Cellobiose & + & + & + & - & - & + & + \\
\hline D-Fructose & + & + & + & - & + & - & + \\
\hline D-Galactose & + & - & + & + & - & - & - \\
\hline Maltose & + & + & + & + & + & - & + \\
\hline D-Mannose & + & + & + & + & - & - & + \\
\hline Sucrose & - & + & + & - & + & + & + \\
\hline Trehalose & + & + & + & + & - & - & + \\
\hline L-Alanine & + & + & + & + & - & - & + \\
\hline L-Aspartate & + & + & + & + & - & - & + \\
\hline L-Glutamate & + & + & + & + & - & - & + \\
\hline L-Threonine & + & + & + & + & - & - & - \\
\hline D-Glucuronate & - & + & + & ND & + & - & + \\
\hline$\alpha$-Ketoglutarate & + & + & + & + & + & - & + \\
\hline Propionate & + & + & + & + & - & - & + \\
\hline
\end{tabular}


Table 3. Phenotypic variability of strains of Photobacterium swingsii sp. nov.

Strains: 1, CAIM 1393 ${ }^{\mathrm{T}}$; 2, CAIM 1394; 3, CAIM 1395; 4, CAIM 1119; 5, CAIM 1206; 6, CAIM 1439. +, Positive; W, weakly positive; - , negative.

\begin{tabular}{|c|c|c|c|c|c|c|}
\hline Characteristic & 1 & 2 & 3 & 4 & 5 & 6 \\
\hline \multicolumn{7}{|l|}{ Utilization of: } \\
\hline DL-Lactate & + & - & - & + & + & - \\
\hline D-Mannitol & - & - & + & - & - & + \\
\hline Putrescine & - & - & + & - & - & + \\
\hline \multicolumn{7}{|l|}{ Production of: } \\
\hline$N$-Acetyl- $\beta$-glucosaminidase & + & + & + & - & + & - \\
\hline Cystine arylamidase & $\mathrm{w}$ & $\mathrm{w}$ & $\mathrm{w}$ & - & - & $\mathrm{w}$ \\
\hline Valine arylamidase & + & + & + & - & $\mathrm{w}$ & + \\
\hline Growth at $35{ }^{\circ} \mathrm{C}$ & + & - & + & - & - & - \\
\hline ONPG ( $\beta$-galactosidase $)$ test & + & + & + & - & - & - \\
\hline
\end{tabular}

and amplified using the $\mathrm{GTG}_{5}$ primer (5'-GTGGTGGTGGTGGTG-3'). The amplification products were electrophoretically resolved on a $20 \times 20 \mathrm{~cm} 1.2 \%$ agarose gel at $90 \mathrm{~V}$ in $1 \times \mathrm{TAE}$ buffer at room temperature for $140 \mathrm{~min}$. The resulting bands were analysed using GelCompar II version 4.5 (Applied Maths). A similarity matrix was calculated with the Jaccard coefficient (Kosman \& Leonard, $2005)$ with a band-position tolerance of $0.59 \%(0.34 \%$ optimization) and a dendrogram was constructed with the Ward algorithm. The six isolates showed genomic homogeneity and were clearly differentiated from the reference strains (Fig. 2).

The DNA G $+\mathrm{C}$ content of selected isolates, strains CAIM $1393^{\mathrm{T}}$, CAIM 1439 and CAIM 1394, was determined by quantitative PCR as described by Gonzalez \& Saiz-Jimenez (2002) with some modifications. Cells were prepared in
$50 \mathrm{ml}$ TSB plus $2.0 \% \mathrm{NaCl}$ under constant agitation, pelleted by centrifugation at 4000 r.p.m. at $4{ }^{\circ} \mathrm{C}$ for 30 min, washed with $1 \times$ TAE buffer, resuspended gently in $467 \mu \mathrm{l} 1 \times$ TAE and lysed with $50 \mu \mathrm{l} 10 \%$ SDS and $4 \mu \mathrm{l}$ $20 \mathrm{mg}$ proteinase $\mathrm{K} \mathrm{ml}^{-1}$ at $37{ }^{\circ} \mathrm{C}$ for $45 \mathrm{~min}$ and $65{ }^{\circ} \mathrm{C}$ for $15 \mathrm{~min}$. DNA was extracted with $550 \mu \mathrm{l}$ phenol/chloroform/ isoamyl alcohol (24:24:1; Sigma). After centrifugation (14000 r.p.m. at room temperature for $5 \mathrm{~min}$ ), the upper aqueous phase was transferred to a Phase Lock Gel tube (5Prime), washed with $1 \mathrm{vol}$. phenol/chloroform/isoamyl alcohol, incubated with $4 \mu \mathrm{l}$ Rase (Promega) at $37^{\circ} \mathrm{C}$ for $30 \mathrm{~min}$ and washed with 1 vol. chloroform/isoamyl alcohol. Finally, the DNA was precipitated with 0.1 vol. cold sodium acetate and 0.6 vol. cold 2-propanol and collected by spooling onto a heat-sealed Pasteur pipette. The DNA concentration was measured spectrophotometrically and adjusted to $1 \mu \mathrm{g} \mu \mathrm{l}^{-1}$. For the quantitative PCR, $6 \mu \mathrm{l}$ DNA solution was mixed with $7.5 \mu \mathrm{l}$ of $0.1 \mu \mathrm{l}$ SYBR Green I (Molecular Probes) $\mathrm{ml}^{-1}, 7.5 \mu \mathrm{l} 1 \times \mathrm{SSC}$ and $54.0 \mu \mathrm{l}$ water (total $75 \mu \mathrm{l}$ ) and $25 \mu \mathrm{l}$ was dispensed in triplicate in wells of a 96-well microtitre plate. An iCycler real-time thermocycler (3.0; Bio-Rad) was used for thermal denaturation with the following protocol: $25{ }^{\circ} \mathrm{C}$ for $15 \mathrm{~min}, 0.2{ }^{\circ} \mathrm{C}$ increments for $12 \mathrm{~s}$ until $100{ }^{\circ} \mathrm{C}$ was reached and a final step of $60{ }^{\circ} \mathrm{C}$ for $30 \mathrm{~min}$. Fluorimetric measurements were taken during the temperature increase every $0.2{ }^{\circ} \mathrm{C}$. The melting temperature $\left(T_{\mathrm{m}}\right)$ was calculated using the negative first derivative of the temperature versus fluorescence $(-\mathrm{d} F / \mathrm{d} T)$. The percentage of guanine and cytosine was calculated using a formula obtained from the thermal denaturation analysis of six strains with published whole-genome sequences and, therefore, known DNA G+C contents: Bacillus subtilis CECT 461 (43.5 mol\%), Lactobacillus lactis CECT 4433 (35.3 mol\%), Escherichia coli CECT 433 (50.8 mol\%), Pseudomonas aeruginosa CECT 4122 (66.6 mol\%), Corynebacterium glutamicum CECT 77 (53.8 mol\%) and Vibrio

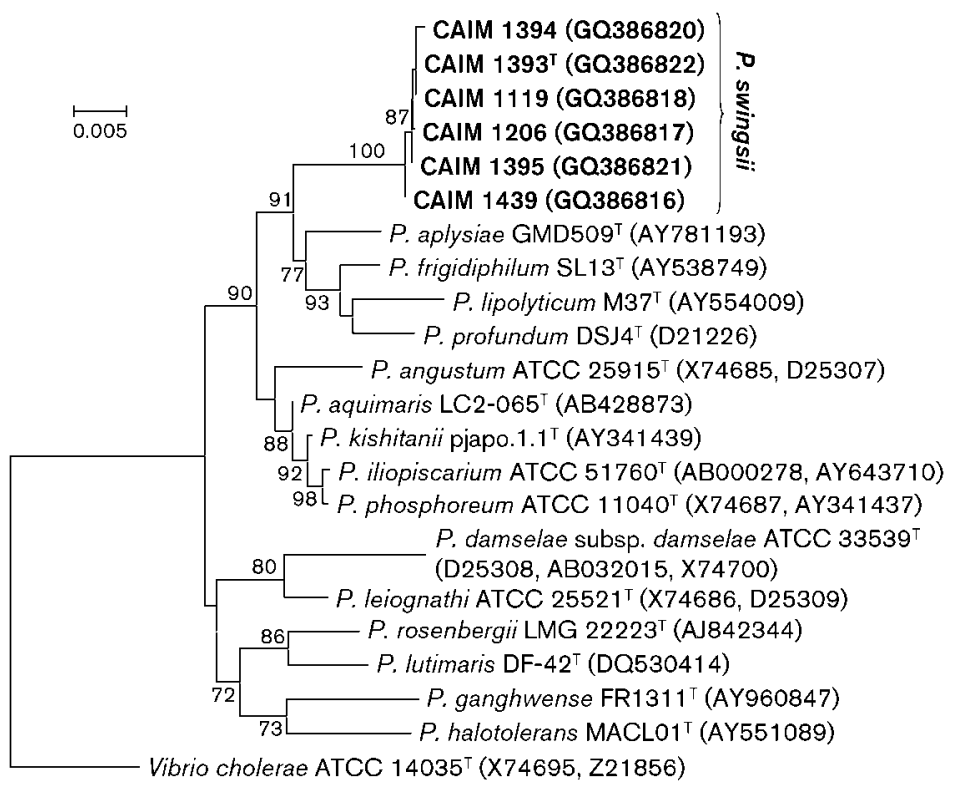

Fig. 1. Neighbour-joining dendrogram, based on almost-complete (1336 bp) 16S rRNA gene sequences, showing the position of strains of Photobacterium swingsii sp. nov. among their closest phylogenetic neighbours. When more than one sequence from a strain was available, the consensus was used. Bootstrap values based on 1000 replicates are shown at branch nodes. A consensus of two sequences from Vibrio cholerae ATCC $14035^{\top}$ was used as an outgroup. Bar, 0.005 substitutions per nucleotide position. 


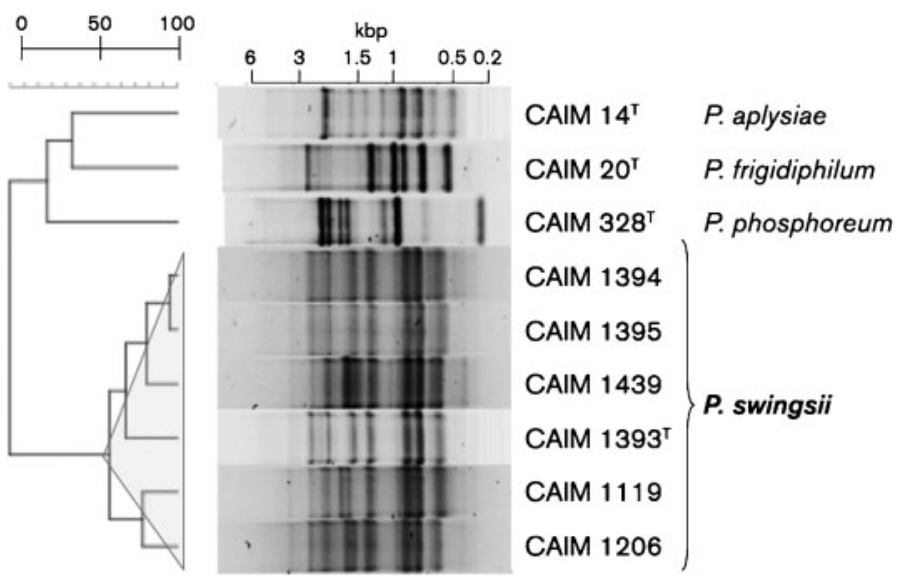

Fig. 2. Genomic comparison of strains of Photobacterium swingsii sp. nov., based on rep-PCR analysis.

campbellii ATCC BAA-1116 (45.4 mol\%) [this last strain had been originally assigned to Vibrio harveyi, but was recently reassigned to $V$. campbellii by Lin et al. (2010)]. The formula obtained was $\mathrm{G}+\mathrm{C}$ content $(\mathrm{mol} \%)=2.002 \times T_{\mathrm{m}}-111.5$ $\left(R^{2}=0.97\right)$. The DNA $\mathrm{G}+\mathrm{C}$ contents determined were $46.7 \mathrm{~mol} \% \quad\left(T_{\mathrm{m}} \quad 79.0^{\circ} \mathrm{C}\right)$ for strain CAIM $1393^{\mathrm{T}}$, $47.5 \mathrm{~mol} \%\left(T_{\mathrm{m}} 79.4{ }^{\circ} \mathrm{C}\right)$ for strain CAIM 1439 and $48.7 \mathrm{~mol} \%\left(T_{\mathrm{m}} 80.0{ }^{\circ} \mathrm{C}\right)$ for strain CAIM 1394.

For DNA-DNA hybridization, genomic DNA was extracted using a DNeasy Blood \& Tissue kit (Qiagen). The hydroxyapatite/microtitre plate method (Ziemke et al., 1998) with a hybridization temperature of $60{ }^{\circ} \mathrm{C}$ was used. DNA-DNA relatedness was determined between strains CAIM $1393^{\mathrm{T}}$ and CAIM 1439 and P. aplysiae CAIM $14^{\mathrm{T}}$ and $P$. frigidiphilum CAIM $20^{\mathrm{T}}$. Reciprocal reactions were performed and DNA-DNA relatedness was calculated as the mean of at least three replications. DNA-DNA relatedness between strain CAIM $1393^{\mathrm{T}}$ and P. aplysiae CAIM $14^{\mathrm{T}}$ was $51.4 \%$ (reciprocal value $53.8 \%$ ), between strain CAIM $1393^{\mathrm{T}}$ and P. frigidiphilum CAIM $20^{\mathrm{T}}$ was $44.0 \%(50.0 \%)$ and between strains CAIM $1393^{\mathrm{T}}$ and CAIM 1439 was $86.5 \%(89.6 \%)$.

On the basis of phenotypic, genotypic and chemotaxonomic characterization, the six isolates belong to a novel Photobacterium species, for which the name Photobacterium swingsii sp. nov. is proposed.

\section{Description of Photobacterium swingsii sp. nov.}

Photobacterium swingsii (swing'si.i. N.L. gen. n. swingsii of Swings, in honour of the Belgian microbiologist Jean Swings).

The species description is based on data for six isolates. Cells are Gram-negative, small coccobacilli. Facultatively anaerobic. Positive for oxidase, catalase (except strain CAIM 1395), nitrate reduction, gelatin hydrolysis (except strain CAIM 1119), arginine dihydrolase and VogesProskauer reaction. Negative for urease, lysine decarboxylase, ornithine decarboxylase, tryptophan deaminase (except strain CAIM 1395), citrate and production of
$\mathrm{H}_{2} \mathrm{~S}$ and indole. Sensitive to the vibriostatic agent O/129 $(10$ and $150 \mu \mathrm{g})$. Grows with 3 and $6 \% \mathrm{NaCl}$, but not with 0 or $10 \% \mathrm{NaCl}$; only strain CAIM 1395 grows with $8 \%$ $\mathrm{NaCl}$. Grows at $4{ }^{\circ} \mathrm{C}$ (except strain CAIM 1395), $20{ }^{\circ} \mathrm{C}$ and $30{ }^{\circ} \mathrm{C}$, but not at $35^{\circ} \mathrm{C}$ (except strains CAIM $1393^{\mathrm{T}}$ and CAIM 1395) or $40{ }^{\circ} \mathrm{C}$. As sole sources of carbon, utilizes amygdalin (except strain CAIM 1119), L-arabinose, cellobiose, D-fructose, D-galactose, D-glucosamine, D-glucose, maltose, D-mannose, melibiose (except strain CAIM 1395), D-ribose, D-salicin, trehalose, methanol, glycerol, L-alanine, glycine, L-aspartate, L-glutamate, L-glutamine, L-ornithine, L-threonine, acetate, citrate, fumarate, ketoglutarate, pyruvate, propionate and succinate, but not lactose (except strain CAIM 1395), sucrose, D-xylose, myo-inositol, D-sorbitol, L-histidine (except strain CAIM 1395), L-leucine (except strain CAIM 1395), L-lysine, L-rhamnose, D-galacturonate, D-gluconate (except strain CAIM 1395), D-glucuronate, malate, $p$-hydroxybenzoate or $\gamma$-aminobutyrate (except strain CAIM 1395). Produces acid phosphatase, alkaline phosphatase, esterase lipase (C8), lipase (C14), leucine arylamidase, naphthol-AS-BI-phosphohydrolase and esterase (C4) (weak; except strain CAIM 1119), but not $\alpha$-chymotrypsin, $\alpha$-fucosidase, $\alpha$-galactosidase, $\beta$-galactosidase, $\beta$-glucuronidase, $\beta$-glucosidase, $\alpha$-glucosidase (except strain CAIM 1119; weak) or $\alpha$-mannosidase. Variable for utilization of DL-lactate, D-mannitol and putrescine, production of $N$-acetyl- $\beta$-glucosaminidase, cystine arylamidase and valine arylamidase and ONPG ( $\beta$-galactosidase) test. The DNA G $+\mathrm{C}$ content is $46.7-$ $48.7 \mathrm{~mol} \%$ (type strain $46.7 \mathrm{~mol} \%$ ).

The type strain, CAIM $1393^{\mathrm{T}}\left(=\mathrm{CECT} 7576^{\mathrm{T}}\right)$, was isolated from the haemolymph of wild spider crabs (Maja. brachydactyla) from the Canary Islands, Spain. Five other strains were isolated from the same source and from homogenates of cultured Pacific oysters (Crassostrea gigas) from north-western Mexico (Table 1).

\section{Acknowledgements}

We thank Oswaldo Palenzuela (CSIC, Instituto de Acuicultura de Torre de la Sal, Spain) for use of the iCycler and the Spanish 
Collection of Type Cultures (CECT) for providing reference strains. We are grateful to Carmen Bolán Mejía and Roxana Atondo for technical help and to Ión Laucirica and José E. Fernández-Palacios for collecting haemolymph from the spider crabs. This study was funded by the INIA project (grant no. RTA-2008-00063), the JACUMAR project 'Cría de centolla Maja sp.', Spain, and the FOSEMARNAT project (grant no. 2004-01-33), Mexico.

\section{References}

Beijerinck, M. W. (1889). Le Photobacterium luminosum, bactérie lumineuse de la Mer du Nord. Arch Neerl Sci Exactes Nat 23, 401-427 (in French).

Cabanillas-Beltran, H., Llausas-Magana, E., Romero, R., Espinoza, A., Garcia-Gasca, A., Nishibuchi, M., Ishibashi, M. \& Gomez-Gil, B. (2006). Outbreak of gastroenteritis caused by the pandemic Vibrio parahaemolyticus O3: K6 in Mexico. FEMS Microbiol Lett 265, 76-80.

Felsenstein, J. (1985). Confidence limits on phylogenies: an approach using the bootstrap. Evolution 39, 783-791.

Gonzalez, J. M. \& Saiz-Jimenez, C. (2002). A fluorimetric method for the estimation of $\mathrm{G}+\mathrm{C}$ mol\% content in microorganisms by thermal denaturation temperature. Environ Microbiol 4, 770-773.

Kosman, E. \& Leonard, K. J. (2005). Similarity coefficients for molecular markers in studies of genetic relationships between individuals for haploid, diploid, and polyploid species. Mol Ecol 14, 415-424.

Kumar, S., Tamura, K., Jakobsen, I. B. \& Nei, M. (2001). MEGA2: molecular evolutionary genetics analysis software. Bioinformatics 17 , $1244-1245$.
Lin, B., Wang, Z., Malanoski, A. P., O'Grady, E. A., Wimpee, C. F., Vuddhakul, V., Alves, N., Thompson, F. L., Gomez-Gil, B. \& Vora, G. J. (2010). Comparative genomic analyses identify the Vibrio harveyi genome sequenced strains BAA-1116 and HY01 as Vibrio campbellii. Environ Microbiol Rep 2, 81-89.

Macián, M. C., Ludwig, W., Aznar, R., Grimont, P. A. D., Schleifer, K. H., Garay, E. \& Pujalte, M. J. (2001). Vibrio lentus sp. nov., isolated from Mediterranean oysters. Int J Syst Evol Microbiol 51, 14491456.

Nogi, Y., Masui, N. \& Kato, C. (1998). Photobacterium profundum sp. nov., a new, moderately barophilic bacterial species isolated from a deep-sea sediment. Extremophiles 2, 1-7.

Saitou, N. \& Nei, M. (1987). The neighbor-joining method: a new method for reconstructing phylogenetic trees. Mol Biol Evol 4, 406425.

Seo, H. J., Bae, S. S., Yang, S. H., Lee, J. H. \& Kim, S. J. (2005). Photobacterium aplysiae sp. nov., a lipolytic marine bacterium isolated from eggs of the sea hare Aplysia kurodai. Int J Syst Evol Microbiol 55, 2293-2296.

Tamura, K., Nei, M. \& Kumar, S. (2004). Prospects for inferring very large phylogenies by using the neighbor-joining method. Proc Natl Acad Sci U S A 101, 11030-11035.

Yoon, J. H., Lee, J. K., Kim, Y. O. \& Oh, T. K. (2005). Photobacterium lipolyticum sp. nov., a bacterium with lipolytic activity isolated from the Yellow Sea in Korea. Int J Syst Evol Microbiol 55, 335-339.

Ziemke, F., Höfle, M. G., Lalucat, J. \& Rosselló-Mora, R. (1998). Reclassification of Shewanella putrefaciens Owen's genomic group II as Shewanella baltica sp. nov. Int J Syst Bacteriol 48, 179-186. 